\title{
Effects of high altitude and season on fasting heat production in the yak Bos grunniens or Poephagus grunniens
}

\author{
Xing-Tai Han*, Ao-Yun Xie, Xi-Chao Bi, Shu-Jie Liu and Ling-Hao Hu \\ Institute of Animal Science, Qinghai Academy of Animal and Veterinary Sciences, 810003, Xining, Qinghai, China
}

(Received 28 August 2001 - Revised 21 February 2002 - Accepted 15 March 2002)

\begin{abstract}
Thirty growing yaks Bos grunniens or Poephagus grunniens, $1 \cdot 0-3 \cdot 5$ years and $50-230 \mathrm{~kg}$, from their native altitudes $(3000-4000 \mathrm{~m})$, were used to study the basal metabolism in this species and to evaluate the effects of high altitude and season on the energy metabolism. Fasting heat production (FHP) was measured at altitudes of 2260, 3250 and $4270 \mathrm{~m}$ on the Tibetan plateau in both the summer and the winter, after a $90 \mathrm{~d}$ adaptation period at each experimental site. Gas exchanges of the whole animals were determined continuously for 3d (4-5 times per d, 10-12 min each time) after a $96 \mathrm{~h}$ starvation period, using closed-circuit respiratory masks. Increasing altitude at similar ambient temperature (Ta) did not affect $(P>0 \cdot 10)$ FHP in the summer, but decreased $(P<0.05)$ it at different Ta in the winter. However, the decrease of FHP in the winter was mainly due to the decrease of Ta instead of the increase of altitude. In the summer, the respiratory rate, heart rate and body temperature were unaffected by altitude, except for a decrease $(P<0.05)$ in body temperature at $4270 \mathrm{~m}$; in the winter, they were decreased $(P<0.05)$ by increasing altitude. In both seasons, the RER was decreased $(P<0.05)$ by increasing altitude. At all altitudes for all groups, the daily FHP was higher $(P<0.05)$ in the summer $\left(\mathrm{Ta} 6-24^{\circ} \mathrm{C}\right)$ than in the winter $\left(\mathrm{Ta} 0\right.$ to $\left.-30^{\circ} \mathrm{C}\right)$, and the Ta-corrected FHP averaged on $920 \mathrm{~kJ} / \mathrm{kg}$ body weight ${ }^{0.52}$ at Ta $8-14^{\circ} \mathrm{C}$ and on $704 \mathrm{~kJ} / \mathrm{kg}$ body weight ${ }^{0.52}$ at $\mathrm{Ta}-15^{\circ} \mathrm{C}$ respectively. We conclude that in the yak high altitude has no effect on the energy metabolism, whereas the cold ambient temperature has a significant depressing effect. The results confirm that the yak has an excellent adaptation to both high altitude and extremely cold environments.
\end{abstract}

High altitude: Season: Fasting heat production: Yak

High-altitude environments are characterised by a lower $\mathrm{O}_{2}$ pressure and a lower temperature than low-altitude environments at similar latitudes. Low $\mathrm{O}_{2}$ pressure can reduce the ability to load $\mathrm{O}_{2}$ in the lung (Turek et al. 1973; Bencowwitz et al. 1982) and thus may reduce the maximal aerobic capacity of mammals experiencing low $\mathrm{O}_{2}$ pressure (Rosenmann \& Morrison, 1975; West, 1984). Subsequently, both maximal and basal $\mathrm{O}_{2}$ consumption are reduced, as observed in newborn mammals and small- to medium-sized adult species exposed to high altitude (Mortola \& Rezzonico, 1988; Mortola et al. 1989; Frappell et al. 1992), although the colder thermal environment at high altitude may result in thermal acclimation that increases the maximal aerobic metabolic rate. In relatively large species, however, $\mathrm{O}_{2}$ consumption is not found to decrease constantly during hypoxia (Piiper et al. 1966; Forster et al. 1976, 1981; Blaxter, 1978). In human subjects studied at thermoneutrality, a drop in $\mathrm{O}_{2}$ consumption is usually absent during hypoxia, and more often the BMR is significantly but transiently elevated (Kellogg et al. 1957; Hannon et al. 1969, 1976, Hannon \& Sudman, 1973, Hannon, 1978; Moore et al. 1987; Armellini et al. 1997; Mawson et al. 2000). Considerable results have accumulated regarding the energy metabolism or $\mathrm{O}_{2}$ consumption at high altitude. However, the response of $\mathrm{O}_{2}$ consumption and ventilation to hypoxia is controversial, and little is known about the energy metabolism in large species that are native to high altitude and about the combined effects of cold exposure and high altitude on the energy metabolism in mammals.

The yak (Poephagus grunniens or Bos grunniens) is one of the world's most remarkable domestic animals, a large mammal living on the 'roof of the world', as the Qinghai-Tibet Plateau is often referred to. The alpine where the yak is found has altitudes ranging from 3000$6000 \mathrm{~m}$, and there is no absolutely frost-free period

\footnotetext{
Abbreviations: BW, body weight; FHP, fasting heat production; Ta, ambient temperature.

* Corresponding author: Dr Xing-Tai Han, present address: Instituto di Zootechnica, Facoltà di Agraria, Università Cattolica del Sacro Cuore, 29100, Piacenza, Italy, fax +390523 599276, email xingtaihan@yahoo.ca
} 
during any part of the year. The territory is thus marked by severe climate at high altitudes and with grazing resources restricted by very short growing seasons, and also marked by treacherous terrain in some of the alpine regions. Some 14 million yaks live and provide food, transport, shelter and fuel where few other animals will survive. Experiments were therefore conducted, using the yak as subject, at altitudes of 2260, 3250 and $4270 \mathrm{~m}$ on the QinghaiTibet Plateau to measure the basal energy metabolism and to evaluate the effects of high altitude and season on the energy metabolism in this species native to high altitude.

\section{Materials and methods}

\section{Experimental sites, animals and management}

The experiments were conducted both in cold and warm seasons on the Qinghai-Tibet Plateau in western China. The experimental sites selected were Qinghai Academy of Animal and Veterinary Sciences (E 101 46 , N $36^{\circ} 37^{\prime}$ ), Tiepujia Pasture Improvement Station (E $99^{\circ} 35^{\prime}$, $\mathrm{N} 37^{\circ} 05^{\prime}$ ) and Maduo Veterinary Station (E 98 $13^{\prime}$, N $\left.34^{\circ} 55^{\prime}\right)$. The Academy is in the agricultural area, and the two stations are located on typical alpine meadow. The altitudes at these sites are 2260, 3250 and $4270 \mathrm{~m}$ and the measured air pressures are 576,515 and $454 \mathrm{mmHg}$ respectively. The mean values for air temperature recorded in the last decade at these sites are $17 \cdot 2,10 \cdot 5$ and $7 \cdot 5^{\circ} \mathrm{C}$ in July, and $-7 \cdot 7,-15 \cdot 2$ and $-16 \cdot 8^{\circ} \mathrm{C}$ in January respectively. There is no absolutely frost-free period during any part of the year at 3250 and $4270 \mathrm{~m}$.

In total, thirty growing yaks (Bos grunniens or Poephagus grunniens), age 1.0-3.5 years and body weight (BW) 50$230 \mathrm{~kg}$, were used. The animals were selected from several individual farms on the Qinghai-Tibet Plateau; the altitude at these farms ranges from 3000 to $4000 \mathrm{~m}$. The yaks were divided into three groups (four per group) according to their age and weight: $1.0-1.5$ years with BW $50-80 \mathrm{~kg}$, $2 \cdot 0-2 \cdot 5$ years with BW $90-120 \mathrm{~kg}$ and $3 \cdot 0-3 \cdot 5$ years with BW 170-230 kg respectively. The experiments lasted for 3 years and thus those that were over 3.5 years were culled and new animals aged 1 year and BW 50$80 \mathrm{~kg}$ were selected again from the same farms to keep the age and BW in the groups unchanged. The selected yaks were first transported to Qinghai Academy of Animal and Veterinary Sciences for 3 months to minimise their wild nature and receive training for various measurements. During the training period, respiratory masks were placed on the animals every morning and afternoon (30 min each time); practice measurements were conducted every morning for respiratory rate, heart rate and rectal temperature, and every week for BW.

The yaks were housed, at an altitude of $2260 \mathrm{~m}$, in a half-open house with access to outside, or placed in a fenced area without any shelter at altitudes of 3250 and $4270 \mathrm{~m}$. Animal housing was similar before and during measurements, except for tethering in the latter case. At an altitude of $2260 \mathrm{~m}$, the animals were fed during the training and non-measurement period with a strawconcentrate diet at twice maintenance level (the maintenance energy requirement was based on the result obtained by Han \& Xie (1991) with growing yaks); at altitudes of 3250 and $4270 \mathrm{~m}$, the animals were allowed to graze during the day, and supplemental feeding was given in the evening in the cold season.

\section{Measurements}

The measurements, which followed the training programme in the first spring, were commenced at an altitude of $2260 \mathrm{~m}$ in the following summer and winter. The animals were then transported to the experimental sites at altitudes of 3250 and $4270 \mathrm{~m}$ in the second and third spring respectively, where the summer and winter measurements were carried out in succession.

In each experiment, twelve animals from the three groups were used. The animals were deprived of feed or grazing for $7 \mathrm{~d}$. Fasted BW was measured in the morning of the 5th and 8th days of starvation; respiratory rate, heart rate and rectal temperature were measured every morning during starvation. Respiratory gases from the whole animal were collected on three consecutive days beginning on the 5th day, using closed-circuit respiratory masks connected to a gas-tight box with a volume of $2 \mathrm{~m}^{3}$ and exit for sample collection. In the summer, the gas collection was performed at 09.00, 15.00, 22.00 and 04.00 hours for $10-12$ min each time. These measurements represented $\mathrm{O}_{2}$ consumption and $\mathrm{CO}_{2}$ release during 08.01-11.00, 11.01-20.00, 20.01-24.00 and 00.0108.00 hours. The protocol for gas collection in the winter was essentially the same as in the summer, except for an additional collection at 18.00 hours representing $16.01-$ 20.00 hours. The time zones were mainly based on changes of ambient temperature (Ta) recorded continuously for 1 week before gas collection. The recorded $\mathrm{Ta}$ in each time zone was averaged at the gas collection hour and appeared relatively stable within the time zone.

Immediately after gas collection, the gas in the collection box was homogenised and a gas sample was taken into a small gas-tight bag for analysis. The total volume of the gas in the collection box was then recorded by withdrawing the gas with a hygrometric gas-flow meter (Shanghai Instrumentation, Shanghai, China) connected to a gas pump. $\mathrm{O}_{2}$ and $\mathrm{CO}_{2}$ concentrations both in the collected gas and in the air were analysed within 20 min after collection, using a semiautomatic gas analyser (LML-2, Shengyang Instrument, Shenyang, China). A sample of collected gas or air $(100 \mathrm{ml})$ was first allowed to pass slowly through a $\mathrm{NaOH}$ solution $(400 \mathrm{~g} / \mathrm{l})$ at least ten times to absorb $\mathrm{CO}_{2}$, and then through a pyrogallic acid solution at least ten times to absorb $\mathrm{O}_{2}$ (stable results were obtained for both after five passes).

During the gas collection days, the standing or lying time of the animals in each time zone was recorded continuously. Temperature, pressure and relative humidity both in the air and in the gas collection boxes were recorded at each collection time.

\section{Calculations and statistics}

Fasted BW over each measurement period was calculated 
as the mean of the initial (5th day of starvation) and final (8th day of starvation) BW. The gas volume in the collection box was converted into volume of standard gas, using formula $\mathrm{V}_{0} \mathrm{P}_{0} / \mathrm{T}_{0}=\mathrm{V}_{1} \mathrm{P}_{1} / \mathrm{T}_{1}$, where $\mathrm{V}_{0}, \mathrm{P}_{0}$ and $\mathrm{T}_{0}$ represent gas volume, air pressure $(760 \mathrm{mmHg})$ and temperature $\left(0^{\circ} \mathrm{C}\right)$ in standard conditions, and $\mathrm{V}_{1}, \mathrm{P}_{1}$ and $\mathrm{T}_{1}$ represent measured gas volume, air pressure and temperature respectively. In further calculations, the variations of relative humidity in the gas collection box were also taken into account. Fasting heat production (FHP), based on the gas volume under standard conditions, was calculated according to the formula of Brouwer (1965). The total FHP in each time zone was calculated as the product of FHP/h and the total hours in the zone, and then corrected into FHP under true standing-lying condition according to the animal's standing time, assuming that the heat production is $15 \%$ higher in the standing than in the lying situation (Han, 1990). The total daily FHP of each animal was calculated as the sum of heat production from all time zones in the day. In order to compare the data between altitudes at similar Ta, the FHP in each time zone was also corrected into $\mathrm{FHP}$ at $8-14^{\circ} \mathrm{C}$ in the summer or at $-15^{\circ} \mathrm{C}$ in the winter according to Han et al. (1992), assuming that in the yak FHP is unchanged from 8 to $14^{\circ} \mathrm{C}$, decreases with decrease of Ta from 8 to $-20^{\circ} \mathrm{C}\left(14.6 \mathrm{~kJ} / \mathrm{kg} \mathrm{BW}^{0.52} \mathrm{per}^{\circ} \mathrm{C}\right)$, and increases as $\mathrm{Ta}$ is below $-20^{\circ} \mathrm{C}\left(18.4 \mathrm{~kJ} / \mathrm{kg} \mathrm{BW}^{0.52}\right.$ per $\left.{ }^{\circ} \mathrm{C}\right)$ or above $15^{\circ} \mathrm{C}$ $\left(10.5 \mathrm{~kJ} / \mathrm{kg} \mathrm{BW}^{0.52}\right.$ per $\left.{ }^{\circ} \mathrm{C}\right)$. The RER is defined as $\mathrm{CO}_{2}$ production : $\mathrm{O}_{2}$ consumption. Data were analysed by ANOVA with animal, age or BW group and altitude, with means per animal and per altitude as the experimental unit. Differences between the winter and summer at the same altitude and same BW were analysed by $t$ test. Variables were considered unaffected by altitude and season or not significantly different between groups if $P>0 \cdot 10$.

\section{Results}

\section{Animal and gas exchange}

The yaks in each age group looked well and all animals survived during the $7 \mathrm{~d}$ starvation at the three altitudes in both seasons. No respiratory problem or discomfort was observed in the animals during gas collection. There was no detectable $\mathrm{CH}_{4}$ in the collected air; $\mathrm{CO}_{2}$ and $\mathrm{O}_{2}$ in the gas-tight box at the end of each collection were approximately $1-2 \%$ and $13-18 \%$ respectively, which were higher and lower by one to two percentage units than those in the air respectively.

\section{The heart rate, respiratory rate and rectal temperature}

Changes in the heart rate, respiratory rate and rectal temperature are shown in Fig. 1. All of the variables rapidly decreased in $48 \mathrm{~h}$ after the beginning of the starvation but there was a small increase at $72 \mathrm{~h}$ of the starvation, after which they appeared stable. In the summer, the three variables recorded at $3250 \mathrm{~m}$ were similar to those recorded at $2260 \mathrm{~m}$, but the body temperature significantly decreased $(P<0.05)$ and the heart rate slightly $(P<0.10)$ decreased at altitude $4270 \mathrm{~m}$, whereas the respiratory rate remained unchanged; in the winter, the variables decreased $(P<0.05)$ with increase of altitude. There was no significant difference in these variables between age groups, but the values were significantly higher $(P<0.05)$ in the summer than in the winter at all experimental sites. In addition, significantly elevated hyperpnoea was observed when Ta was over $14^{\circ} \mathrm{C}$, especially at $3250 \mathrm{~m}$.

\section{Fasting heat production}

The FHP obtained in the summer and expressed as $\mathrm{kJ} / \mathrm{kg}$ $\mathrm{BW}^{0 \cdot 75}$ per $\mathrm{d}$ are shown in Table 1. The recorded Ta during measurements at 2260, 3250 and $4270 \mathrm{~m}$ averaged on $12 \cdot 5,13 \cdot 2$ and $10.0^{\circ} \mathrm{C}$, ranging from $6-20,8-23$ and $4-17^{\circ} \mathrm{C}$ respectively. The FHP measured under these temperatures was not affected by altitude. The Ta-corrected FHP also remained fairly constant irrespective of increase in altitude. All the corrected data were thus pooled and subjected to model $y=a x^{\mathrm{b}}$ for analysis by the least square method, and the following equation between FHP and BW was found: FHP $(\mathrm{kJ} / \mathrm{d})=920 \mathrm{BW}^{0.52}(n$ 36, $r$ $0 \cdot 85)$.

The FHP measured in the winter and also expressed as $\mathrm{kJ} / \mathrm{kg} \mathrm{BW}^{0.75}$ per $\mathrm{d}$ are given in Table 2. The Ta during measurements at 2260, 3250 and $4270 \mathrm{~m}$ averaged on $-4.6,-12 \cdot 1$ and $-14 \cdot 5^{\circ} \mathrm{C}$, ranging from -15 to 0 , -30 to -3 and -34 to $-10^{\circ} \mathrm{C}$ respectively. The FHP measured under the natural temperature significantly decreased with increase of altitude. This decrease, however, disappeared when the data were corrected into FHP at $-15^{\circ} \mathrm{C}$. On this basis, the corrected data were also analysed by the least squares method and the following equation was established: FHP $(\mathrm{kJ} / \mathrm{d})=704 \mathrm{BW}^{0.52}(n$ 36, $r$ 0.81).

A summary of FHP measured both in the summer and winter, and expressed as $\mathrm{kJ} / \mathrm{kg} \mathrm{BW}^{0.52}$ per $\mathrm{d}$, is shown in Table 3. The FHP both under the natural and corrected Ta was significantly higher in the summer than in the

Table 1. Fasting heat production $\left(\mathrm{kJ} / \mathrm{kg}\right.$ body weight $\left.{ }^{0.75}\right)$ of yaks at different altitudes in the summer*

(Values are means for four yaks per age group)

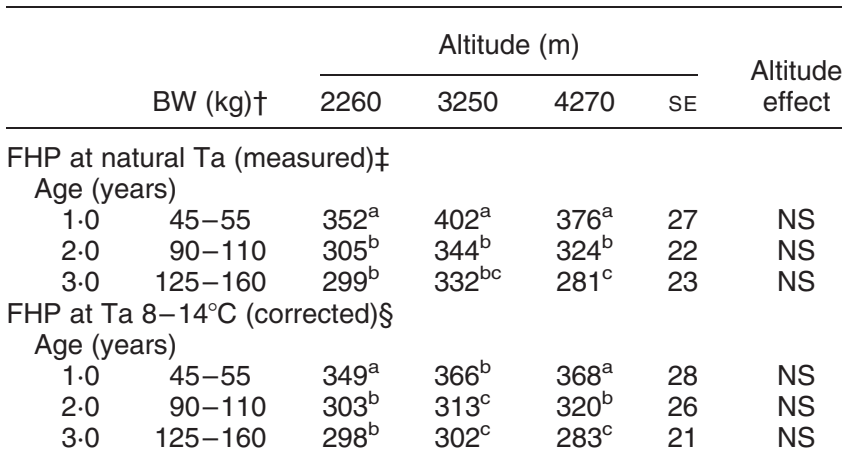

BW, body weight; FHP, fasting heat production; Ta, ambient temperature.

a,b,c Mean values within a column with unlike superscript letters were significantly different $(P<0.05)$.

${ }^{*}$ For details of diets and procedures, see p. 190.

$\dagger$ Fasted BW recorded during measurement.

† Ta $6-20^{\circ} \mathrm{C}$ at $2260 \mathrm{~m}, 8-23^{\circ} \mathrm{C}$ at $3250 \mathrm{~m}, 4-17^{\circ} \mathrm{C}$ at $4270 \mathrm{~m}$.

$\S$ FHP was corrected according to Han et al. (1992). 
(a)

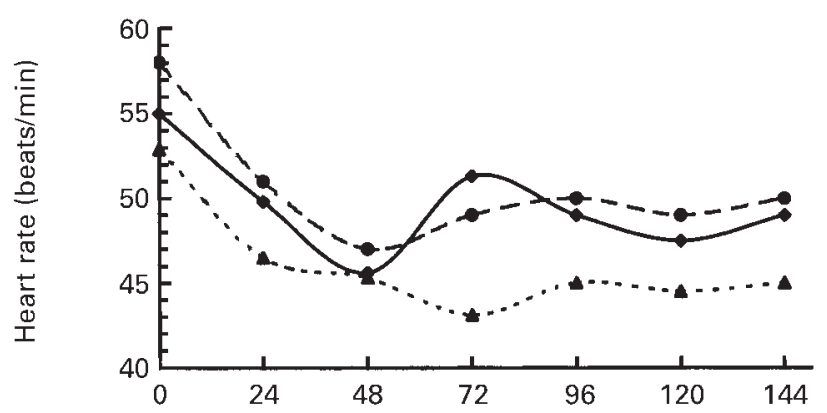

(b)

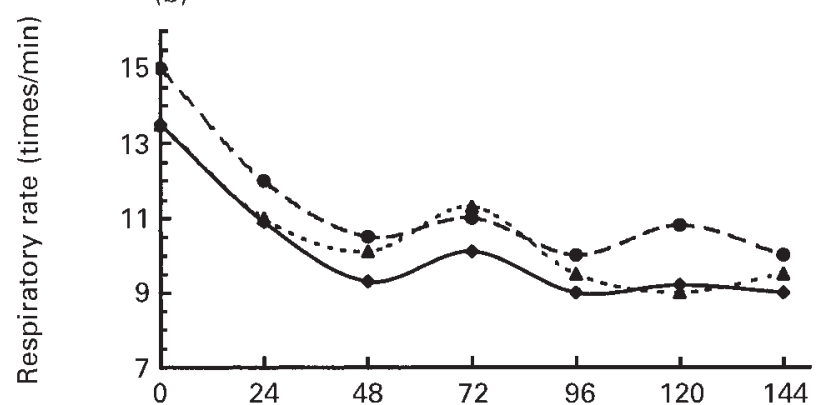

(c)

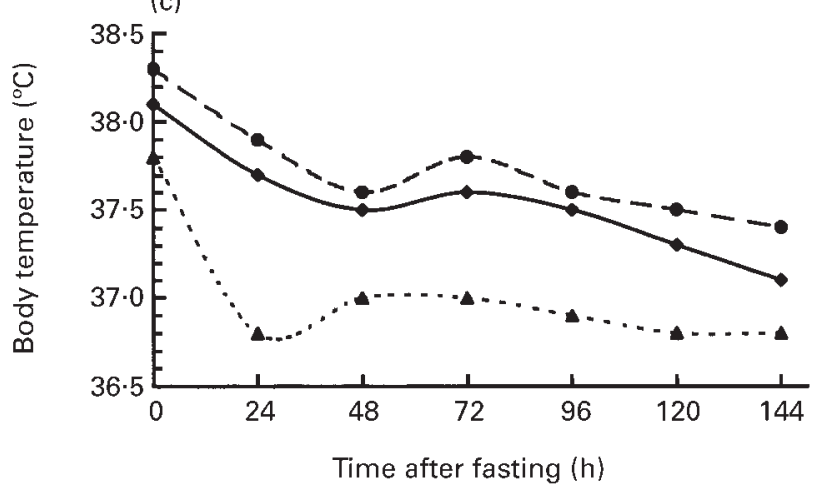

(d)

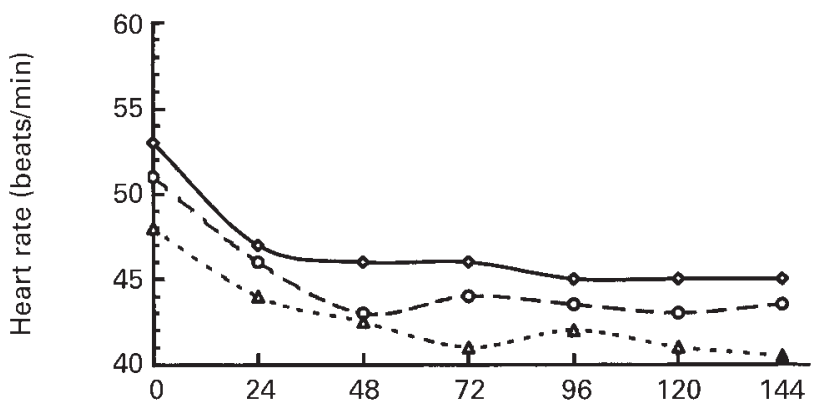

(e)
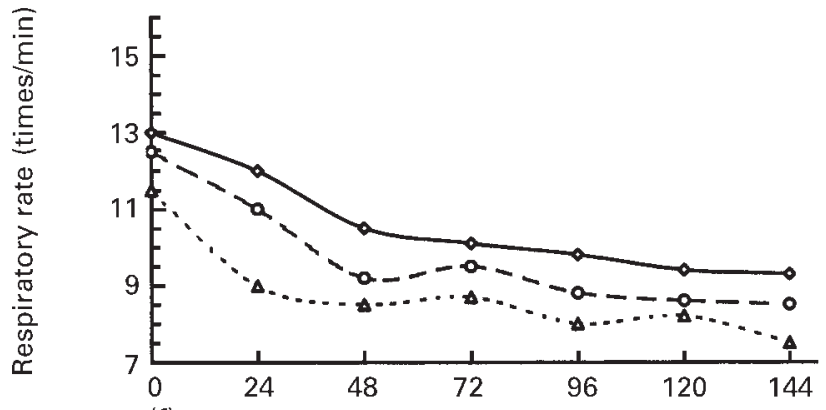

(f)
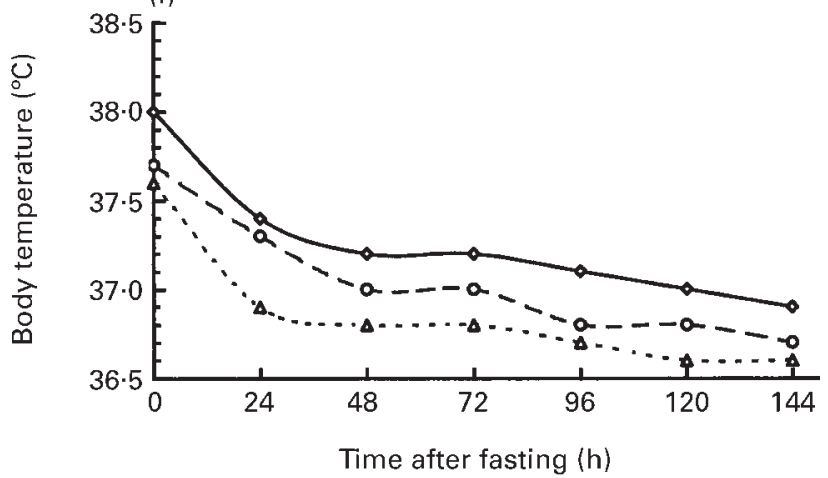

Fig. 1. Changes in heart rate, respiratory rate and body temperature in the summer $(a, b, c)$ and winter (d,e,f) at different altitudes (summer:

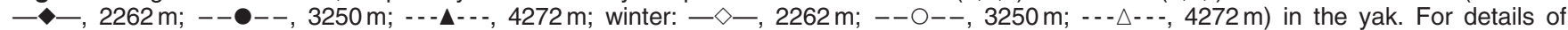
diets and procedures, see p. 190. Values are means for twelve yaks.

winter. There was no difference in FHP in this way between altitudes, except for a decrease of FHP in the winter under natural Ta.

\section{$R E R$}

RER was similar between age groups and between seasons at all experimental sites. The RER at 2260, 3250 and $4270 \mathrm{~m}$ averaged on $0.744,0.696$ and 0.545 respectively, showing a significant decrease from 2260 to $3250 \mathrm{~m}$ $(P<0.05)$ and from 3250 to $4270 \mathrm{~m}(P<0 \cdot 01)$.

\section{Standing time}

There was no difference in standing time between age groups at all experimental sites. The data from the three groups at 2260,3250 and $4270 \mathrm{~m}$ averaged on $46 \cdot 7,55.4$ and $47.2 \%$ in the summer and $45.2,41.5$ and $38.7 \%$ in the winter respectively. The standing time in the summer was higher $(P<0.05)$ at $3250 \mathrm{~m}$ than at 2260 and
$4270 \mathrm{~m}$. The values in the winter, showing a difference $(P<0.05)$ between 2260 and $4270 \mathrm{~m}$, indicated a decrease trend with increase of altitude. Except for the data at $2260 \mathrm{~m}$, the standing time during measurements was higher $(P<0.01)$ in the summer than in the winter.

\section{Discussion}

As presented on p. 190, the major aim of the present study was to evaluate the effects of altitude and season on the energy metabolism in the yak. The study could have been carried out at a feeding level near maintenance or $50 \%$ maintenance energy requirement. However, control of feeding level is quite difficult under grazing conditions. Furthermore, reduction of intake occurs at high altitude (Gill \& Pugh, 1964). On the other hand, the yak is sometime forced to starve for several days or more by heavy snow in the winter on the Tibet plateau. Thus, data on the BMR in this species appear important, particularly for the effort of providing the animals with feed that 
Table 2. Fasting heat production $\left(\mathrm{kJ} / \mathrm{kg}\right.$ body weight $\left.{ }^{0.75}\right)$ of yaks at different altitude in the winter

(Values are means for four yaks per age group)

\begin{tabular}{|c|c|c|c|c|c|c|}
\hline & \multirow[b]{2}{*}{ BW $(\mathrm{kg}) \S$} & \multicolumn{4}{|c|}{ Altitude (m) } & \multirow{2}{*}{$\begin{array}{l}\text { Altitude } \\
\text { effect }\end{array}$} \\
\hline & & 2260 & 3250 & 4270 & SE & \\
\hline \multicolumn{7}{|c|}{ FHP at natural Ta (measured)\| } \\
\hline \multicolumn{7}{|c|}{ Age (years) } \\
\hline 1.5 & $65-85$ & $333^{a}$ & $293^{a}$ & $268^{a}$ & 22 & * \\
\hline 2.5 & $110-130$ & $299^{a b}$ & $266^{\text {ab }}$ & $241^{\text {ab }}$ & 25 & $\dagger$ \\
\hline 3.5 & $170-200$ & $273^{\mathrm{bc}}$ & $242^{b}$ & $219^{b}$ & 19 & * \\
\hline \multicolumn{7}{|c|}{$\mathrm{FHP}$ at $\mathrm{Ta}-15^{\circ} \mathrm{C}$ (corrected) $\emptyset$} \\
\hline \multicolumn{7}{|c|}{ Age (years) } \\
\hline 1.5 & $65-85$ & $278^{\mathrm{bc}}$ & $263^{a b}$ & $258^{\mathrm{a}}$ & 17 & NS \\
\hline 2.5 & $110-130$ & $249^{\text {cd }}$ & $253^{\mathrm{b}}$ & $242^{\mathrm{ab}}$ & 26 & NS \\
\hline 3.5 & $170-200$ & $227^{d}$ & $235^{\mathrm{b}}$ & $208^{b}$ & 13 & NS \\
\hline
\end{tabular}

BW, body weight; FHP, fasting heat production; Ta, ambient temperature.

$\mathrm{a}, \mathrm{b}, \mathrm{c}, \mathrm{d}$ Mean values within a column with unlike superscript letters were significantly different $(P<0.05)$.

${ }^{*} P<0.05$.

$\dagger P<0.10$.

$\ddagger$ For details of diets and procedures, see p. 190.

$\S$ Fasted BW recorded during measurement.

$\| \mathrm{Ta}-15$ to $0^{\circ} \mathrm{C}$ at $2260 \mathrm{~m},-30$ to $-3^{\circ} \mathrm{C}$ at $3250 \mathrm{~m}$ and -34 to $-10^{\circ} \mathrm{C}$ at $4270 \mathrm{~m}$.

q FHP was corrected according to Han et al. (1992).

meets the minimal daily energy requirement for maintaining survival during starvation periods caused by heavy snow. For these reasons, we starved the yaks during measurements, to avoid nutritive effect and to measure FHP or BMR.

\section{Effect of altitude on energy metabolism}

The response of $\mathrm{BMR}$ or $\mathrm{O}_{2}$ consumption to altitude in mammals has been well documented in the past five decades. Results from published studies have indicated that in newborn mammals and small- to medium-sized adult species the BMR or $\mathrm{O}_{2}$ consumption is reduced during hypoxia (Mortola \& Rezzonico, 1988; Mortola et al. 1989; Frappell et al. 1992), and that in sea-level residents the basal $\mathrm{O}_{2}$ consumption is significantly (Terzioglu \& Aykut, 1954; Kellogg et al. 1957; Grover, 1963; Gill \&

Table 3. Fasting heat production $\left(\mathrm{kJ} / \mathrm{kg}\right.$ body weight $\left.{ }^{0.52}\right)$ of yaks at different altitude in different seasons $\dagger$

(Values are means for twelve yaks per season)

\begin{tabular}{|c|c|c|c|c|c|}
\hline & \multicolumn{4}{|c|}{ Altitude $(\mathrm{m})$} & \multirow{2}{*}{$\begin{array}{l}\text { Altitude } \\
\text { effect }\end{array}$} \\
\hline & 2260 & 3250 & 4270 & SE & \\
\hline \multicolumn{6}{|c|}{ FHP at natural Ta (measured) } \\
\hline Summer & $893^{a}$ & $1026^{a}$ & $929^{a}$ & 55 & NS \\
\hline Winter & $900^{\mathrm{a}}$ & $797^{b}$ & $724^{\mathrm{b}}$ & 39 & * \\
\hline \multicolumn{6}{|c|}{$\mathrm{FHP}$ at Ta $8-14^{\circ} \mathrm{C}$ (summer) and $-15^{\circ} \mathrm{C}$ (winter) (corrected) $\ddagger$} \\
\hline Summer & $887^{a}$ & $934^{\mathrm{a}}$ & $920^{\mathrm{a}}$ & 49 & NS \\
\hline Winter & $749^{b}$ & $749^{\mathrm{b}}$ & $704^{b}$ & 35 & NS \\
\hline
\end{tabular}

FHP, fasting heat production; Ta, ambient temperature.

${ }^{a, b}$ Mean values within a column with unlike superscript letters were significantly different $(P<0.05)$

${ }^{*} P<0.05$.

†For details of diets and procedures, see p. 190

$\ddagger$ FHP was corrected according to Han et al. (1992).
Pugh, 1964; Stock et al. 1978; Moore et al. 1987; Butterfield et al. 1992) but transiently (Kellogg et al. 1957; Hannon et al. 1969, 1976; Hannon \& Sudman, 1973, Hannon, 1978; Moore et al. 1987; Mawson et al. 2000) elevated when they are exposed to high altitude for 1-3 weeks. In the present study, the FHP was not affected by altitude at similar $\mathrm{Ta}$ in the summer, but decreased by increasing altitude at different Ta in the winter. However, the decrease in the winter was related to the decrease of Ta rather than the increase of altitude. Thus, we conclude that high altitude has no effect on the FHP of growing yaks aged from 1-3 years. This conclusion neither supports the hypoxic hypometabolism observed in newborn and small species nor supports the elevated BMR observed in some studies with human subjects.

However, the present results are in good agreement with observation in sheep by Blaxter (1978), who evaluated the effect of simulated altitude on energy metabolism, and could not detect any effect of a reduction in the $\mathrm{O}_{2}$ concentration in the air from 200 to $150 \mathrm{ml} / \mathrm{l}$ on heat production in both fasted or fed conditions, energy retention or heat increment. Our results also agree well with studies with goats (Forster et al. 1981), ponies (Forster et al. 1976), dogs (Hemingway \& Nahas, 1952; Piiper et al. 1966; Bouverot et al. 1981) and human subjects (Dempsey \& Forster, 1982; Armellini et al. 1997; Mawson et al. 2000), which demonstrated that at or slightly below the thermoneutral range, $\mathrm{O}_{2}$ consumption was not significantly affected during hypoxia. In the 1960s, Hannon et al. (1969, 1976) Hannon \& Sudman (1973) Hannon (1978) performed the most thorough study of the question to date in women, and their subjects demonstrated only a transient elevation in BMR in the first week when taken to $4300 \mathrm{~m}$ and provided with a diet ad libitum. Hannon et al. (1976) concluded that there was no change in energy requirement at high altitude to maintain BW and composition as compared with that at sea level.

In the present study, the yaks used are the native animal on the Tibet plateau where the altitude ranges from 3000 $6000 \mathrm{~m}$, and before each measurement they were at the experimental sites at least for 3 months for adaptation to the new altitudinal environments. The FHP at similar Ta in all age groups remained fairly constant irrespective of increase in altitude from 2260 to $4270 \mathrm{~m}$. In another study (Han et al. 2002), we measured, in the same conditions, the FHP in yellow cattle; we found that an increase of altitude from 2260 to $4270 \mathrm{~m}$ increased FHP. These results suggest that for animals permanently living at high altitude, low air $\mathrm{O}_{2}$ concentration has no effect on their basal energy metabolism. The yak has been reported to have a larger heart and lung and a higher proportion of red blood cells and haemoglobin than other kinds of cattle, and these variables are found to be higher in yaks living in a higher altitude area than in a relatively lower altitude area (for review see Cai \& Wiener, 1995). These characteristics and changes can compensate for the deficiency in $\mathrm{O}_{2}$ concentration caused by high altitude, and thus may explain the stability of FHP at different altitudes. In human subjects, Zhuang et al. (1993) compared twenty-seven lifelong Tibetan residents of Lhasa, Tibet, China $(3658 \mathrm{~m})$ with thirty acclimatised Han nationality 
newcomers matched for age, body size, and extent of exercise training. They concluded that lifelong Tibetan residents of high altitude neither hypoventilated nor exhibited blunted hypoxic ventilatory responses nor reduced $\mathrm{O}_{2}$ consumption, as compared with acclimatised Han nationality newcomers. In addition, in the rat, Hayes $(1989 a, b)$ found that the maximal metabolic rate of freshly captured wild deer mice (Peromyscus maniculatus) was not significantly different between high- and low-altitude populations tested at their native altitudes, though the BMR was reduced at high altitude. He concluded that deer mice that are native to, and develop at, high altitude are able to compensate for low $\mathrm{O}_{2}$ pressure and sustain a maximal metabolic rate similar to that of low altitude mice. All of these observations imply that the reduction of $\mathrm{O}_{2}$ consumption in small species and the elevation in human subjects, both exposed to hypoxia for a short time in most cases, may be due to the deficiency of adaptation of animals and human subjects to high altitude, and suggest that the extent of adaptation could be a main factor determining energy metabolism during hypoxia.

It is thought that in mammals the hypoxic hypometabolism is mostly related to the decrease in thermogenesis. Because in small animals the thermogenesis represents a larger component of resting $\mathrm{O}_{2}$ consumption, the magnitude of hypoxic hypometabolism would be larger in young animals or small species. Conversely, in the larger adult species, hyperpnoea would occur, and the thermogenesis is a small component of resting $\mathrm{O}_{2}$ consumption, thus the hypoxic hypometabolism is minimal. This may be another explanation of the inconsistancy between studies with newborn animals or small species and with larger adult species including yaks used in the present experiment.

The use of heart-rate measurement as a method for estimating energy metabolism of free-ranging animals was advocated by Webster (1967) and adopted by others (Yamamoto et al. 1979; Richards \& Lawrence, 1984; Brosh et al. 1994). In the present study, changes in heart rate, respiratory rate and body temperature are essentially in agreement with changes in FHP measured under natural temperature, especially in the winter. The significant decrease of these variables with increase of altitude in the winter, and the small decrease in heart rate and the significant decrease in body temperature at $4270 \mathrm{~m}$ in the summer, may be due to the decrease of Ta at high altitude, since significantly decreased heart rate, respiratory rate and body temperature in fasted yaks have been reported to be related to decrease in Ta (Han et al. 1992). Another possible explanation of the decrease of body temperature may be that hypoxia induces a decrease in the set point for body temperature regulation in the brain, which in turn results in a decrease in $\mathrm{O}_{2}$ demand (for review see Gautier, 1996).

The RER significantly decreased, in the present study, with increase of altitude. Similarly, our study with yellow cattle revealed a decrease in RER from 0.750 to 0.555 when altitude was increased from 3250 to $4270 \mathrm{~m}$ (Han et al. 2002). We cannot explain such a low RER at high altitude. Technical problems should be excluded because the methods used were the same for all altitudes.
Perhaps the low RER is a physiological phenomenon, since there is evidence that arterial $\mathrm{O}_{2}$ pressure is lower and $\mathrm{CO}_{2}$ pressure is higher in lifelong high-altitude residents (Chiodi, 1957; Lahiri, 1968).

\section{Effect of season on fasting heat production}

In mammals, gaseous metabolism increases in the cold due to the increase in the rate of thermogenesis. In fasted dairy cows, for example, the FHP significantly increases with decrease of $\mathrm{Ta}$ when $\mathrm{Ta}$ is lower than $18^{\circ} \mathrm{C}$ (Blaxter \& Wainman, 1961). In the present study, however, the FHP was significantly lower in the cold season than in the warm season, suggesting that in the yak the FHP decreases with decrease of Ta in the cold. Our result is consistent with the previous study with yaks by Han et al. (1992), who conducted 223 measurements in a wide temperature range from -30 to $23^{\circ} \mathrm{C}$ at altitude $3250 \mathrm{~m}$, and revealed that the FHP remained unchanged from $8-14^{\circ} \mathrm{C}$, decreased with decrease of Ta from 8 to $-20^{\circ} \mathrm{C}$, and increased as Ta was below $-20^{\circ} \mathrm{C}$ or above $15^{\circ} \mathrm{C}$. When the measured FHP in the winter was corrected, according to Han et al. (1992), into FHP at $-15^{\circ} \mathrm{C}$, the difference in FHP between altitudes became minimal and non-significant. This suggests that the change of FHP was due to difference of Ta rather than altitude.

However, it is possible that the FHP decrease in the winter is a response of altitude-temperature interaction, since the hypoxic hypometabolism is thought to be more apparent when $\mathrm{O}_{2}$ consumption is relatively high, either in small or young mammals at subnormal ambient temperatures or in large mammals exposed to the cold (for review see Gautier, 1996). For example, in conscious rats the increase in ventilation was less and the hypometabolic responses were greater at low Ta than at high Ta during hypoxia (Gautier \& Bonora, 1992; Saiki et al. 1994). Similarly in toads (Hou \& Huang, 1999) and Nautilus pompilius (Staples et al. 2000), the resting or basal $\mathrm{O}_{2}$ consumption decreased significantly in mild hypoxia $\left(\mathrm{O}_{2}\right.$ pressure $120-140 \mathrm{mmHg})$ at low $\mathrm{Ta}$ and in moderate hypoxia $\left(\mathrm{O}_{2}\right.$ pressure $60-80 \mathrm{mmHg}$ ) at high $\mathrm{Ta}$, though it did not differ significantly between altitudes in the toad (Hou \& Huang, 1999). In our present study, FHP was significantly lower at extremely low $\mathrm{Ta}$ (winter) than at moderate $\mathrm{Ta}$ (summer) at any of the three altitudes. This could be that the combination of low $\mathrm{Ta}$ and low $\mathrm{O}_{2}$ pressure suppresses metabolic rate, enhancing hypoxia tolerance. Hill (1959) emphasised that Ta was a crucial variable in determining the magnitude of the hypometabolic response to hypoxia.

Another possibility might be that there are special mechanisms involved in regulation of thermogenesis in the yak during the cold season. Visible and anatomical evidence includes the animal's small and short conformation, fleecy and thicker coat in the cold season, thicker skin and less sweat glands (for review see Cai \& Wiener, 1995), which may prevent heat dissipation. Physiological evidence, however, has not been found in the literature to explain the relationship between heat production and $\mathrm{Ta}$, especially low Ta below $0^{\circ} \mathrm{C}$. The present study, in agreement with our previous observation (Han et al. 1992), suggests that in the yak the critical temperature causing 
increase in heat production is quite low, and thus may explain the normal survival of the yak in the harsh environments $\left(-30\right.$ to $\left.-40^{\circ} \mathrm{C}\right)$ in the cold seasons on the Qinghai-Tibetan Plateau.

\section{The fasting heat production in the yak}

Based on the fact that there was no effect of altitude on FHP, the data were pooled and analysed by the least squares method, and it was found that the FHP both in the summer and winter was highly related to $\mathrm{BW}^{0.52}$. For a given season, the established equation gives the same value of the FHP for all yaks from 45 to $220 \mathrm{~kg}$ when $\mathrm{FHP}$ is expressed as $\mathrm{kg} \mathrm{BW}^{0.52}$. In fed growing yaks weighing from 50 to $200 \mathrm{~kg}$, Hu et al. (1994) concluded, by the least squares method, that the body surface area, which is associated with heat loss, was also related to $\mathrm{BW}^{0.52}$. In fasted yaks weighing from 80 to $150 \mathrm{~kg}$, constant excretion of endogenous urine $\mathrm{N}$ was observed when it was expressed as $\mathrm{g} / \mathrm{kg} \mathrm{BW}^{0.52}$ (X-T Han and A$\mathrm{Y}$ Xie, unpublished results). This evidence suggests that $\mathrm{BW}^{0.52}$ is a suitable unit to express heat production and metabolism in the yak.

In the present study, the FHP of the 1- and 2-year-old yaks in the summer is similar to that observed by Han et al. (1993) with yak steers in the same ages at similar Ta. FHP expressed as $\mathrm{kJ} / \mathrm{kg} \mathrm{BW}^{0.75}$ per $\mathrm{d}$ from all age groups in the summer, however, is lower than those summarised by the Agricultural Research Council (1980) with eighty-eight growing cattle. The average FHP $\left(303 \mathrm{~kJ} / \mathrm{kg} \mathrm{BW}^{0.75}\right)$ in the warm season from the 2- and 3 -year-old groups is also lower than the $322 \mathrm{~kJ} / \mathrm{kg} \mathrm{BW}^{0.75}$ widely used in beef cattle (National Research Council, 1984). Assuming that the pattern of energy metabolism in the adult yaks is in line with that in the growing yaks, then the FHP at thermoneutral range $\left(8-14^{\circ} \mathrm{C}\right)$ in adult yaks weighing approximately $230-250 \mathrm{~kg}$ (fasted BW $200-220 \mathrm{~kg}$ ), according to the equation obtained in the warm season in our present study, could be predicted to be $273 \mathrm{~kJ} / \mathrm{kg} \mathrm{BW}^{0.75}$. This value also seems lower than $293 \mathrm{~kJ} / \mathrm{kg} \mathrm{BW}^{0.75}$ accepted in non-lactating and non-pregnant adult cows (Agricultural Research Council, 1980). The lower energy metabolism might be a result of adaptation of the yak to low $\mathrm{O}_{2}$ concentration in the air, to the cold environment and the long-term undernutrition in the cold season that lasts for more than 6 months each year on the Tibet plateau. In fed yaks, low $\mathrm{NH}_{3}$ and volatile fatty acid concentrations (Han et al. 1998) and low dietary protein degradability (Xue \& Han, 1999) in the rumen, and low concentrations of free amino acids (Han et al. 2001) in the blood were observed. In addition, low maintenance protein requirements (Xue et al. 1994) and low body surface area (Hu et al. 1994) of this species have been reported previously. These studies concluded that the low metabolic rate of the yak is a species characteristic adapted to the harsh conditions on the Tibet plateau.

\section{Conclusion}

In summary, the results presented here demonstrate that high altitude has no effect on the energy metabolism at similar ambient temperature both in the cold and warm seasons, whereas the cold environment significantly reduces the FHP in the yak at its native altitudes. Overall, the FHP in the yak seems low compared with those of other species. The significant reduction of FHP in the winter may be due either to an altitude-temperature interaction, or to the anatomical and physiological adaptation of the yak to the cold, or to both. The lower metabolic rate near the thermoneutral range $\left(8-14^{\circ} \mathrm{C}\right)$, and its absence in response to increase of altitude, may be related to the species characteristics well adapted to the low $\mathrm{O}_{2}$ concentration, extremely cold environment and long-term undernutrition in the Tibet plateau. The results provide additional information on the energy metabolism of large mammals that normally live at high altitude and in a harsh environment.

\section{Acknowledgements}

The authors would like to thank Y. P. Zhao, X. W. Zhang, G. F. Qiu, W. J. Cai, Y. Z. Feng, Q. L. Xu and C. Y. Hu for their assistance over the experiments.

\section{References}

Agricultural Research Council (1980) The Nutrient Requirement of Ruminant Livestock. London: Commonwealth Agriculture Bureaux.

Armellini F, Zamboni M, Robbi R, Todesco T, Bissoli L, Mino A, Angelini G, Micciolo R \& Bosello O (1997) The effects of high altitude trekking on body composition and resting metabolic rate. Hormone and Metabolic Research 29, 458-461.

Bencowitz HZ, Wagner PD \& West JB (1982) Effect of change in $P_{\mathrm{O}_{2}}$ on exercise tolerance at high altitude: a theoretical study. Journal of Applied Physiology 53, 1487-1495.

Blaxter KL (1978) The effect of stimulated altitude on the heat increment of feed in sheep. British Journal of Nutrition 39, $659-661$.

Blaxter KL \& Wainman FW (1961) Environmental temperature and the energy metabolism and heat emission of steers. Journal of Agricultural Science, Cambridge 56, 81-90.

Bouverot P, Collin R, Favier R, Flandrois R \& Sebert P (1981) Carotid chemoreceptor function in ventilatory and circulatory $\mathrm{O}_{2}$ convection of exercising dogs at low and high altitude. Respiratory Physiology 43, 147-167.

Brosh A, Beneke G, Fennell S, Wright D, Aharoni Y \& Young B (1994) Prediction of energy expenditure by heart rate measurements in cattle: the effect of exercise, diet and sun radiation. In Energy Metabolism of Farm Animals. Proceedings of the 13th International Symposium, EAAP Publication no. 76, pp. 35-38 Mojácar, Spain: EAAP.

Brouwer E (1965) Report of subcommittee on constants and factors. In Energy Metabolism, EAAP Publication no. 11, pp. 441 [KL Blaxter, editor]. London: Academic Press.

Butterfield GE, Gates J, Fleming S, Brooks GA, Sutton JR \& Reeves JT (1992) Increased energy intake minimizes weight loss in men at high altitude. Journal of Applied Physiology 72, 1741-1748.

Cai L \& Wiener G (1995) The Yak. FAO Regional Office for Asia and the Pacific, Bangkok, Thailand.

Chiodi H (1957) Respiratory adaptations to chronic high altitude hypoxia. Journal of Applied Physiology 10, 81-87.

Dempsey JA \& Forster HV (1982) Mediation of ventilatory adaptations. Physiological Review 62, 262-346. 
Forster HV, Bisgard GE \& Klein JP (1981) Effect of peripheral chemorecepter denervation on acclimatization of goats during hypoxia. Journal of Applied Physiology 50, 392-398.

Forster HV, Bisgard GE, Rasmussen B, Orr JA, Buss DD \& Manohar M (1976) Ventilatory control in peripheral chemorecepter denervated ponies during chronic hypoxemia. Journal of Applied Physiology 41, 878-885.

Frappell P, Lanthier C, Baudinette RV \& Mortola JP (1992) Metabolism and ventilation in acute hypoxia: a comparative analysis in small mammalian species. American Journal of Physiology 262, R1040-R1046.

Gautier H (1996) Interactions among metabolic rate, hypoxia, and control of breathing. Journal of Applied Physiology 81, $521-527$.

Gautier H \& Bonora M (1992) Ventilatory and metabolic responses to cold and hypoxia in intact and carotid body-denervated rats. Journal of Applied Physiology 73, 847-854.

Gill MB \& Pugh LGC (1964) Basal metabolism and respiration in men living at $5800 \mathrm{~m}(19,000 \mathrm{ft})$. Journal of Applied Physiology 19, 949-954.

Grover RF (1963) Basal oxygen uptake of man at high altitude. Journal of Applied Physiology 18, 909-912.

Han XT (1990) Factors affecting fasting metabolism in ruminants. Qinghai Journal of Animal and Veterinary Sciences 20(4), $30-33$.

Han XT, Bi XC, Xie AY \& Hu LH (1993) The energy metabolism of growing yaks. Qinghai Animal Industry 1, 20-23.

Han XT, Chen J \& Han ZK (1998) Ruminal nitrogen metabolism and the flows of nitrogen fractions reaching the duodenum of growing yaks fed diets containing different levels of crude protein. Acta Zoonutrimenta Sinica 10(1), 34-43.

Han XT, Liu SJ, Bi XC, Wang WB, Xie AY \& Hu LH (1992) The thermoneutrality zone and the regularity of heat production beyond the zone in fasted growing yaks. Qinghai Journal of Animal and Veterinary Sciences 22(2), 18-20.

Han XT \& Xie AY (1991) The maintenance energy requirement of growing yaks. Qinghai Journal of Animal and Veterinary Sciences 21(1), 10-11.

Han XT, Xie AY, Bi XC, Liu SJ \& Hu LH (2002) Effects of altitude, ambient temperature and solar radiation on fasting heat production in yellow cattle. British Journal of Nutrition (In the Press)

Han XT, Xue B, Du JZ \& Hu LH (2001) Net fluxes of peptide and amino acid across mesenteric-drained and portal-drained viscera of yak cows fed a straw-concentrate diet at maintenance level. Journal of Agricultural Science, Cambridge 136, 119-127.

Hannon JP (1978) Comparative altitude adaptability of men and women. In Environmental Stress: Individual Human Adaptations, pp. 335-350 [LJ Folinsbee, JA Wagner, JF Borgia, BL Drinkwater, JA Gliner and JF Bedi, editors]. New York, NY: Academic.

Hannon JP, Klain GJ, Sudman DM \& Sulivan FJ (1976) Nutritional aspects of high altitude exposure in women. American Journal of Clinical Nutrition 29, 604-613.

Hannon JP, Shields JL \& Harris CW (1969) Anthropometric changes associated with high altitude acclimatization in women. American Journal of Physiological Anthropology 31, $77-84$.

Hannon JP \& Sudman DM (1973) Basal metabolic and cardiovascular function of women during altitude acclimatization. Journal of Applied Physiology 34, 471-477.

Hayes JP (1989a) Field and maximal metabolic rates of deer mice (Peromyscus maniculatus) at low and high altitudes. Physiological Zoology 62, 732-744.

Hayes JP (1989b) Altitude and seasonal effects on aerobic metabolism of deer mice. Journal of Comparative Physiology 159B, 453-459.
Hemingway A \& Nahas GG (1952) Effect of varying degrees of hypoxia on temperature regulation. American Journal of Physiology 170, 426-433.

Hill JR (1959) The oxygen consumption of new-born and adult mammals. Its dependence on the oxygen tension in the inspired air and on the environmental temperature. Journal of Physiology, London 149, 346-373.

Hou PC \& Huang SP (1999) Metabolic and ventilatory responses to hypoxia in two altitudinal populations of the toad, Bufo bankorensis. Comparative Biochemistry and Physiology 124A, 413-421.

Hu LH, Xie AY \& Han XT (1994) Study on the body surface areas of growing yaks and cattle. Chinese Journal of Animal Science 30(6), 9-10.

Kellogg RH, Pace N, Archibald ER \& Vaughan BE (1957) Respiratory response to inspired $\mathrm{CO}_{2}$ during acclimatization to an altitude of 12,470 feet. Journal of Applied Physiology 11, $665-671$.

Lahiri S (1968) Alveolar gas pressures in man with life-time hypoxia. Respiratory Physiology 4, 373-386.

Mawson JT, Braun B, Rock PB, Moore LG, Mazzeo R \& Butterfield GE (2000) Women at altitude: energy requirement at $4300 \mathrm{~m}$. Journal of Applied Physiology 88, 272-281.

Moore LG, Cymerman A, Huang SY, McCullough RE, McCullough RG, Rock PB, Young A, Young P, Weil JV \& Reeves JT (1987) Propranolol blocks metabolic rate increase but not ventilatory acclimatization to $4,300 \mathrm{~m}$. Respiratory Physiology 70, 195-205.

Mortola JP \& Rezzonico R (1988) Metabolic and ventilatory rates in newborn kittens during acute hypoxia. Respiratory Physiology 73, 55-68.

Mortola JP, Rezzonico R \& Lanthier C (1989) Ventilation and oxygen consumption during acute hypoxia in newborn mammals: a comparative analysis. Respiratory Physiology 78, $31-43$.

National Research Council (1984) Nutrient Requirements of Beef Cattle. Washington, DC: National Academy Press.

Piiper J, Cerretelli P, Cuttica F \& Mangili F (1966) Energy metabolism and circulation in dogs exercising in hypoxia. Journal of Applied Physiology 21, 1143-1149.

Richards JI \& Lawrence PR (1984) The estimation of energy expenditure from heart rate measurements in working oxen and buffalo. Journal of Agricultural Science, Cambridge 102, $711-717$.

Rosenmann M \& Morrison P (1975) Metabolic response of highland and lowland rodents to simulated high altitudes and cold. Comparative Biochemistry and Physiology 51A, 523-530.

Saiki C, Matsuoka T \& Mortola JP (1994) Metabolic-ventilatory interaction in conscious rats: effect of hypoxia and ambient temperature. Journal of Applied Physiology 76, 1594-1599.

Staples JF, Hershkowitz JJ \& Boutilier RG (2000) Effects of ambient $P_{\mathrm{O}_{2}}$ and temperature on oxygen uptake in Nautilus pompilius. Journal of Comparative Physiology 170B, 231-236.

Stock MJ, Norton NG, Ferro-Luzzi A \& Evans E (1978) Effect of altitude on dietary-induced thermogenesis at rest and during light exercise in man. Journal of Applied Physiology 45, 345-349.

Terzioglu M \& Aykut R (1954) Variations in basal metabolic rate at $1.85 \mathrm{~km}$ altitude. Journal of Applied Physiology 7, 329-332.

Turek Z, Kreuzer F \& Hoofd LJC (1973) Advantage or disadvantage of decrease of blood oxygen affinity for tissue oxygen supply at hypoxia. Pflügers Archiv 342, 185-197.

Webster AJF (1967) Continuous measurement of heart rate as an indicator of the expenditure of sheep. British Journal of Nutrition 21, 769-785.

West JB (1984) Human physiology at extreme altitudes on Mount Everest. Science 223, 784-788. 
Xue B, Chai ST, Liu SJ \& Wang WB (1994) Study on the protein requirement of growing yaks. In Yak Production in Central Asian Highlands. Proceedings of the First International Congress on the Yak, pp. 198-201. Lanzhou: Gansu.

Xue B \& Han XT (1999) A comparative study on the protein degradability of foodstuffs in the rumen of growing yaks and growing Holsteins. Chinese Journal of Herbivore Science 1(3), 3-7.
Yamamoto S, McLean JA \& Downie AJ (1979) Estimation of heat production from heart rate measurements in cattle. British Journal of Nutrition 42, 507-513.

Zhuang J, Droma T, Sun S, Janes C, McCullough RE, McCullough RG, Cymerman A, Huang SY, Reeves JT \& Moore LG (1993) Hypoxic ventilatory responsiveness in Tibetan compared with Han residents of $3658 \mathrm{~m}$. Journal of Applied Physiology 74, $303-311$. 